\title{
A Case of IgG4-related Pharyngolaryngitis
}

\author{
Narihisa Suzuki, Masato Fujioka, Yasutomo Araki, \\ Hiroyuki Ozawa and Mitsuhiro Kawaura
}

\begin{abstract}
IgG4-related inflammatory diseases, including autoimmune pancreatitis and Mikulicz syndrome, have become known to physicians as new clinical entities, especially over the past few years. We would like to present a case of IgG4-related oropharyngolaryngitis. We encountered a 80 -year-old male with a severe and intractable inflammation distributed exclusively in the hypopharynx and laryngeal surface of the epiglottis. The patient did not spontaneously recover and the disease was resistant to antibiotics and NSAIDs that were administered for 4 weeks. Frequent fiberscope inspections and punch biopsies failed to provide a diagnosis, and were followed by a detailed examination under laryngomicrosurgery, with multiple tissue samplings under general anesthesia. The samples revealed proliferative, non-malignant inflammatory lesions and the pathology showed IgG4-related symptoms; indicated by all of the criteria including blood and local IgG4 elevation being met. Symptoms were quickly suppressed by a week of steroid infusion drips, followed by a gradual tapering of oral steroids in accordance with a regimen for autoimmune pancreatitis. For many years, ENT physicians have often used corticosteroids empirically for atypical pharyngitis, but usage of steroids on conditions with uncertain criteria has always been criticized. This is, as far as we know, the first report of oropharyngolaryngitis to be associated with IgG4-related symptoms. The case is thought-provoking in that some of those recurrent atypical oropharyngolaryngitis cases might be explained in accordance with this information. Moreover, the results suggest that the serum IgG4 level might be a predictive marker for the requirement of corticosteroids administration.
\end{abstract}

Keywords : pharyngolaryngitis, IgG4-related diseases, autoimmune disease

\section{References}

1）IgG4 関連全身硬化性疾患の診断法の確立と治療方法の開 発に関する研究班・新規疾患, IgG4 関連多臓器リンパ増 殖性疾患（IgG4+MOLPS）の確立のための研究班：IgG4 関連疾患包括診断基準 2011. 日内会誌 101：795-804, 2012.

2) Yamamoto M, Tabeya T, Naishiro $Y$, et al. : Value of serum IgG4 in the diagnosis of IgG4-related disease and in differentiation from rheumatic diseases and other diseases. Mod Rheumatol 22: 419-425, 2012.

3) Umehara H, Okazaki K, Masaki Y, et al. : A novel clinical entity, IgG4-related disease (IgG4RD): general concept and details. Mod Rheumatol 22: 1-14, 2012.

4) Hamano H, Kawa S, Horiuchi A, et al. : High serum IgG4 concentrations in patients with sclerosing pancreatitis. $\mathrm{N}$ Engl J Med 344: 732-738, 2001.

5) Shimatsu A, Oki Y, Fujisawa I, et al. : Pituitary and stalk lesions (infundibulo-hypophysitis) associated with immunoglobulin G4-related systemic disease: an emerging clinical entity. Endocr J 56: 1033-1041, 2009.
6) Lindstrom KM, Cousar JB and Lopes MB : IgG4-related meningeal disease: clinico-pathological features and proposal for diagnostic criteria. Acta Neuropathol 120: 765-776, 2010.

7) Katsura M, Morita A, Horiuchi H, et al. : IgG4-related inflammatory pseudotumor of the trigeminal nerve: another component of IgG4-related sclerosing disease? AJNR Am J Neuroradiol 32: E150-152, 2011.

8) Yamamoto M, Takahashi H, Ohara M, et al. : A new conceptualization for Mikulicz's disease as an IgG4-related plasmacytic disease. Mod Rheumatol 16: 335-340, 2006.

9) Masaki Y, Dong L, Kurose N, et al. : Proposal for a new clinical entity, IgG4-positive multiorgan lymphoproliferative syndrome: analysis of 64 cases of IgG4-related disorders. Ann Rheum Dis 68: 1310-1315, 2009.

10) Li $Y$, Nishihara E, Hirokawa $M$, et al. : Distinct clinical, serological, and sonographic characteristics of hashimoto's thyroiditis based with and without IgG4-positive plasma cells. J Clin Endocrinol Metab 95: 1309-1317, 2010.

11) Kojima M, Hirokawa M, Kuma H, et al. : Distribution of IgG4- 
and/or IgG-positive plasma cells in Hashimoto's thyroiditis: an immunohistochemical study. Pathobiology 77: 267-272, 2010.

12) Dahlgren M, Khosroshahi A, Nielsen GP, et al. : Riedel's thyroiditis and multifocal fibrosclerosis are part of the IgG4related systemic disease spectrum. Arthritis Care Res (Hoboken) 62: 1312-1318, 2010.

13) Kakudo K, Li Y, Hirokawa M, et al. : Diagnosis of Hashimoto's thyroiditis and IgG4-related sclerosing disease. Pathol Int 61: 175-183, 2011.

14) Inoue D, Zen $Y$, Abo H, et al. : Immunoglobulin G4-related lung disease: CT findings with pathologic correlations. Radiology 251: 260-270, 2009.

15) Shigemitsu $H$ and Koss MN : IgG4-related interstitial lung disease: a new and evolving concept. Curr Opin Pulm Med 15: 513-516, 2009.

16) Tsushima K, Tanabe T, Yamamoto $H$, et al. : Pulmonary involvement of autoimmune pancreatitis. Eur J Clin Invest 39: 714-722, 2009 .

17）厚生労働省難治性膵疾患調查研究班 - 日本膵臓学会 : 自己 免疫性膵炎診療ガイドライン 2009. 膵臓 24 Suppl：1-54, 2009.

18）日本膵臓学会 - 厚生労働省難治性膵疾患に関する調查研究 班：自己免疫性萃炎臨床診断基準 2011. 膵蔵 27：17-25, 2012.

19）神澤輝実, 露口利夫, 川崎誠治, 他： IgG4 関連硬化性胆 管炎. 胆道 25：86-93, 2011.

20) Nakazawa T, Ohara H, Sano H, et al. : Cholangiography can discriminate sclerosing cholangitis with autoimmune pancreatitis from primary sclerosing cholangitis. Gastrointest Endosc 60: 937-944, 2004.

21) Umemura T, Zen Y, Hamano H, et al. : Clinical significance of immunoglobulin G4-associated autoimmune hepatitis. J Gastroenterol 46 Suppl 1: 48-55, 2011.

22) Lopes J, Hochwald SN, Lancia N, et al. : Autoimmune esophagitis: IgG4-related tumors of the esophagus. J Gastrointest Surg 14: 1031-1034, 2010.

23) Kamisawa T, Horiguchi S, Hayashi Y, et al. : K-ras mutation in the major duodenal papilla and gastric and colonic mucosa in patients with autoimmune pancreatitis. J Gastroenterol 45: 771-778, 2010.

24) Akitake R, Watanabe T, Zaima C, et al. : Possible involvement of $\mathrm{T}$ helper type 2 responses to Toll-like receptor ligands in IgG4-related sclerosing disease. Gut 59: 542-545, 2010.

25) Uchiyama-Tanaka Y, Mori Y, Kimura T, et al. : Acute tubulointerstitial nephritis associated with autoimmune-related pancreatitis. Am J Kidney Dis 43: e18-25, 2004.

26) Saeki T, Nishi S, Imai N, et al. : Clinicopathological characteristics of patients with IgG4-related tubulointerstitial nephritis.
Kidney Int 78: 1016-1023, 2010.

27) Nishimori I, Kohsaki T, Onishi S, et al. : IgG4-related autoimmune prostatitis: two cases with or without autoimmune pancreatitis. Intern Med 46: 1983-1989, 2007.

28) Ishida M, Hotta M, Kushima R, et al. : IgG4-related inflammatory aneurysm of the aortic arch. Pathol Int 59: 269-273, 2009 .

29) Stone JH, Khosroshahi A, Hilgenberg A, et al. : IgG4-related systemic disease and lymphoplasmacytic aortitis. Arthritis Rheum 60: 3139-3145, 2009.

30) Stone JR : Aortitis, periaortitis, and retroperitoneal fibrosis, as manifestations of IgG4-related systemic disease. Curr Opin Rheumatol 23: 88-94, 2011.

31) Laco J, Steiner I, Holubec T, et al. : Isolated thoracic aortitis: clinicopathological and immunohistochemical study of 11 cases. Cardiovasc Pathol 20: 352-360, 2011.

32) Miyagawa-Hayashino A, Matsumura Y, Kawakami F, et al. : High ratio of IgG4-positive plasma cell infiltration in cutaneous plasmacytosis-is this a cutaneous manifestation of IgG4related disease? Hum Pathol 40: 1269-1277, 2009.

33) Cheuk W, Chan AC, Lam WL, et al. : IgG4-related sclerosing mastitis: description of a new member of the IgG4-related sclerosing diseases. Am J Surg Pathol 33: 1058-1064, 2009.

34) Ogiya A, Tanaka K, Tadokoro Y, et al. : IgG4-related sclerosing disease of the breast successfully treated by steroid therapy. Breast Cancer: Epub ahead of print, 2010.

35) Okazaki K, Uchida K, Matsushita M, et al. : How to diagnose autoimmune pancreatitis by the revised Japanese clinical criteria. J Gastroenterol 42 Suppl 18: 32-38, 2007.

36）川茂 幸：IgG4 関連疾患. 信州医誌 60：193-200, 2012 .

37) Guma M and Firestein GS : IgG4-related diseases. Best Pract Res Clin Rheumatol 26: 425-438, 2012.

38) Khosroshahi A and Stone JH : Treatment approaches to IgG4related systemic disease. Curr Opin Rheumatol 23: 67-71, 2011.

39) Ito T, Nishimori I, Inoue $\mathrm{N}$, et al. : Treatment for autoimmune pancreatitis: consensus on the treatment for patients with autoimmune pancreatitis in Japan. J Gastroenterol 42 Suppl 18: 50-58, 2007.

40）山本元久, 西本憲弘, 田邊谷徹也, 他 : IgG4 関連疾患の 診断マーカーと治療マーカーとしての血清 IgG4 值測定の 有用性. 日臨免疫会誌 35: 30-37, 2012.

41) Zen Y, Fujii T, Harada K, et al. : Th2 and regulatory immune reactions are increased in immunoglobin G4-related sclerosing pancreatitis and cholangitis. Hepatology 45: 1538-1546, 2007.

42）全陽, 中沼 安: IgG4 関連疾患におけるサイトカイ ン発現と制御性 T 細胞の動態. IgG4 関連疾患への誘い(川 茂幸，川野充弘編)。93-97 頁，前田書店，金沢，2010。 